\title{
Population coverage of the Canadian Chronic Disease Surveillance System: a survey of the contents of health insurance registries across Canada
}

\author{
Naomi C. Hamm, MSc (1); Cynthia Robitaille, MSc (2); Joellyn Ellison, MPH (2); Siobhan O'Donnell, MSc (2); \\ Louise McRae, BSc (2); Kimberley Hutchings, MSc (2); Louis Rochette, MSc (3); Karen A.M. Phillips, DVM (4); \\ Mahmoud Azimaee, BSc (5); MaryRose Stang, PhD (6); Rolf Puchtinger, MA (6); Megan McCallum, MPH (7); \\ Aijun Yang, MSc (8); Josh Squires, BSc (9); Yue Liu, MSE (10); Lawrence W. Svenson, PhD (11,12,13); \\ Faisal Shibley, BSc (14); Aakash Amatya, MSc (14); Bin Zhang, PhD (15); James Ayles, BSc (15); Lisa M. Lix, PhD (1)
}

This article has been peer reviewed.

\begin{abstract}
Introduction: Health insurance registries, which capture insurance coverage and demographic information for entire populations, are a critical component of population health surveillance and research when using administrative data. Lack of standardization of registry information across Canada's provinces and territories could affect the comparability of surveillance measures. We assessed the contents of health insurance registries across Canada to describe the populations covered and document registry similarities and differences.
\end{abstract}

Methods: A survey about the data and population identifiers in health insurance registries was developed by the study team and representatives from the Public Health Agency of Canada. The survey was completed by key informants from most provinces and territories and then descriptively analyzed.

Results: Responses were received from all provinces; partial responses were received from the Northwest Territories. Demographic information in health insurance registries, such as primary address, date of birth and sex, were captured in all jurisdictions. Data captured on familial relationships, ethnicity and socioeconomic status varied among jurisdictions, as did start and end dates of coverage and frequency of registry updates. Identifiers for specific populations, such as First Nations individuals, were captured in some, but not all jurisdictions.

Conclusion: Health insurance registries are a rich source of information about the insured populations of the provinces and territories. However, data heterogeneity may affect who is included and excluded in population surveillance estimates produced using administrative health data. Development of a harmonized data framework could support timely and comparable population health research and surveillance results from multi-jurisdiction studies.

\section{Author references:}

1. Department of Community Health Sciences, University of Manitoba, Winnipeg, Manitoba, Canada 2. Public Health Agency of Canada, Ottawa, Ontario, Canada

3. Bureau d'information et d'études en santé des populations, Institut national de santé publique du Québec, Montréal, Quebec, Canada

4. Chief Public Health Office, Prince Edward Island Department of Health and Wellness, Charlottetown, Prince Edward Island, Canada

5. Data Quality and Information Management, ICES, Toronto, Ontario, Canada

6. Population Health Branch, Saskatchewan Ministry of Health, Regina, Saskatchewan, Canada

7. Government of the Northwest Territories, Yellowknife, Northwest Territories, Canada

8. British Columbia Ministry of Health, Victoria, British Columbia, Canada

9. Data and Information Services, Newfoundland and Labrador Centre for Health Information, St. John's, Newfoundland and Labrador, Canada

10. Nova Scotia Department of Health and Wellness, Halifax, Nova Scotia, Canada

11. Analytics and Performance Reporting, Alberta Health, Edmonton, Alberta, Canada

12. Division of Preventive Medicine, School of Public Health, University of Alberta, Edmonton, Alberta, Canada

13. Department of Community Health Sciences, University of Calgary, Calgary, Alberta, Canada

14. Health, Seniors and Active Living, Government of Manitoba, Winnipeg, Manitoba, Canada

15. New Brunswick Department of Health, Fredericton, New Brunswick, Canada

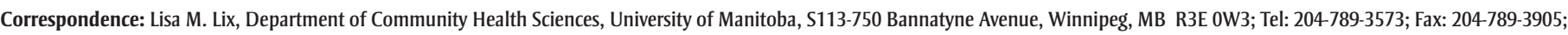
Email: lisa.lix@umanitoba.ca

- All reporting Canadian health insurance registries contain data going back to at least 1996. The earliest year of available data was 1968, in Saskatchewan.

- Some features of registry data, such as change in coverage, primary address, date of birth and sex, were consistent across all reporting jurisdictions. Other features, such as family unit identifiers, socioeconomic status and population identifiers, varied across reporting jurisdictions.

- Differences in Canadian health insurance registries present opportunities for studies that compare the populations covered by provincial/ territorial health insurance plans. Creation of a harmonized data framework would benefit national surveillance initiatives and multijurisdiction studies.

Keywords: health insurance registries, administrative health data, population identifiers 


\section{Introduction}

Administrative health data are data originally collected for purposes of managing and monitoring the health care system. However, these data are also commonly used to measure and describe population health within Canada, ${ }^{1-7}$ because they are routinely collected, inexpensive to use and have nearly complete population coverage. Administrative health data include physician billing claims, hospital discharge abstracts, prescription medication dispensations and health insurance registries. ${ }^{8}$ Health insurance registries are a critical component of population-based surveillance and research studies in Canada, because they contain information about members of provincial or territorial populations who are eligible to receive publicly funded health services. ${ }^{9}$ Understanding the populations captured in health insurance registries and the data that are collected about these populations is essential for comparing health measures between jurisdictions and over time, as well as determining generalizability of these comparisons.

Health care coverage in Canada primarily falls under provincial or territorial jurisdiction. ${ }^{10}$ There is no standard for how data in health insurance registries are collected and coded, or for how different populations, such as those covered by federal health insurance, are identified in registry files. Differences in health insurance registries across Canada can present challenges to the comparability of surveillance and research studies.

The Canadian Chronic Disease Surveillance System (CCDSS) is a network supported by the Public Health Agency of Canada (PHAC) that aims to further the use of Canadian administrative health data for chronic disease surveillance and supports health care planning and health policies and programs. ${ }^{8}$ Through the CCDSS, the provinces and territories provide PHAC with aggregate data derived from administrative health data that are then used to generate national estimates and trends over time for over twenty chronic diseases and conditions. Heterogeneity in the data contained within health insurance registries can affect who is included in or excluded from the CCDSS estimates. It also impacts which jurisdictions can conduct health research and surveillance on specific subpopulations (e.g. First Nations individuals).
There has been limited research on the data contained in Canadian provincial and territorial health insurance registries. The few studies that do exist primarily focus on health insurance registries from a single jurisdiction. ${ }^{5,9,11}$ Two studies focus on the Manitoba health insurance registry, ${ }^{9,11}$ and one provides a brief description of the Quebec registry as part of that province's Integrated Chronic Disease Surveillance System. ${ }^{5}$ Studies that include multiple jurisdictions are limited to reviews; no direct comparisons across jurisdictions have been made. ${ }^{12,13}$ Detailed information about identifiable populations and those individuals who are included in or excluded from population-based health insurance registries could (1) improve our understanding of surveillance estimates produced from CCDSS data, and (2) inform the potential uses of registry data to describe specific subpopulations.

The purpose of this study was to assess the data contained within health insurance registries across Canadian provinces and territories. The objectives were to describe the populations covered and document registry similarities and differences.

\section{Methods}

Data were collected using a survey developed by the project team with input from content experts and advisors at PHAC. As well, the project team received input from research staff at the Manitoba Centre for Health Policy with experience working with population health insurance registry data. The survey included five sections: (1) general information (i.e. indication of province or territory); (2) temporal data coverage; (3) start and end dates of coverage for residents of the province or territory; (4) population characteristics captured in registry data; and (5) population identification. The final draft of the survey was approved by PHAC before distribution. A copy of the survey is available upon request.

A list of key informants from each of the provinces and territories was identified by the project team with input from PHAC. Informants were primarily identified from members of the CCDSS Science Committee and Data Quality Working Group. Informants who held positions that involved working with administrative data were contacted, as they were most likely to be knowledgeable about the registry data in their jurisdiction. In cases where two contacts were available with similar expertise, both were contacted.

In April 2019, the project team emailed the survey to the key respondents, who were given one week to complete it; extensions were provided as needed. Key informants were free to consult other experts in their jurisdiction to complete the survey if needed. If key informants were unable to complete the survey, they were asked to recommend an alternative informant. Phone and email follow-ups were conducted by the project team to clarify responses when needed.

This study was conducted out of the University of Manitoba. Research ethics approval was not required as data were collected on health insurance registry contents, not human participants. ${ }^{14}$

\section{Results}

Thirteen key informants from the 10 provinces responded to the survey (two from Saskatchewan, Manitoba and New Brunswick), and one key informant from the Northwest Territories provided limited information. Where two key informants were consulted, informants worked together to fill out a single survey, which was returned to study researchers. No survey response was received from Yukon or Nunavut, as no one with sufficient expertise (i.e. knowledge of registry data) to address the questions was identified. Key informants included individuals employed by provincial ministries of health and experts associated with population-based research data repositories, such as ICES. Both Saskatchewan and Prince Edward Island indicated that registry staff were consulted when completing the survey.

\section{Temporal data coverage}

Information about temporal coverage of the health insurance registries is provided in Figure 1. The earliest available year of data was reported by Saskatchewan (1968). While Manitoba's key informant reported that the earliest available year of data was from 1984, other published sources indicate this province's health insurance registry data extends back to $1970 .^{9,15}$ However, data from these early years may not be consistently available to all data users and may be difficult to use when generating surveillance and research reports. All provinces reported that "snapshots" (i.e. a 
FIGURE 1

Timelines of data available in Canadian health insurance registries for each participating jurisdiction (excluding the Northwest Territories)

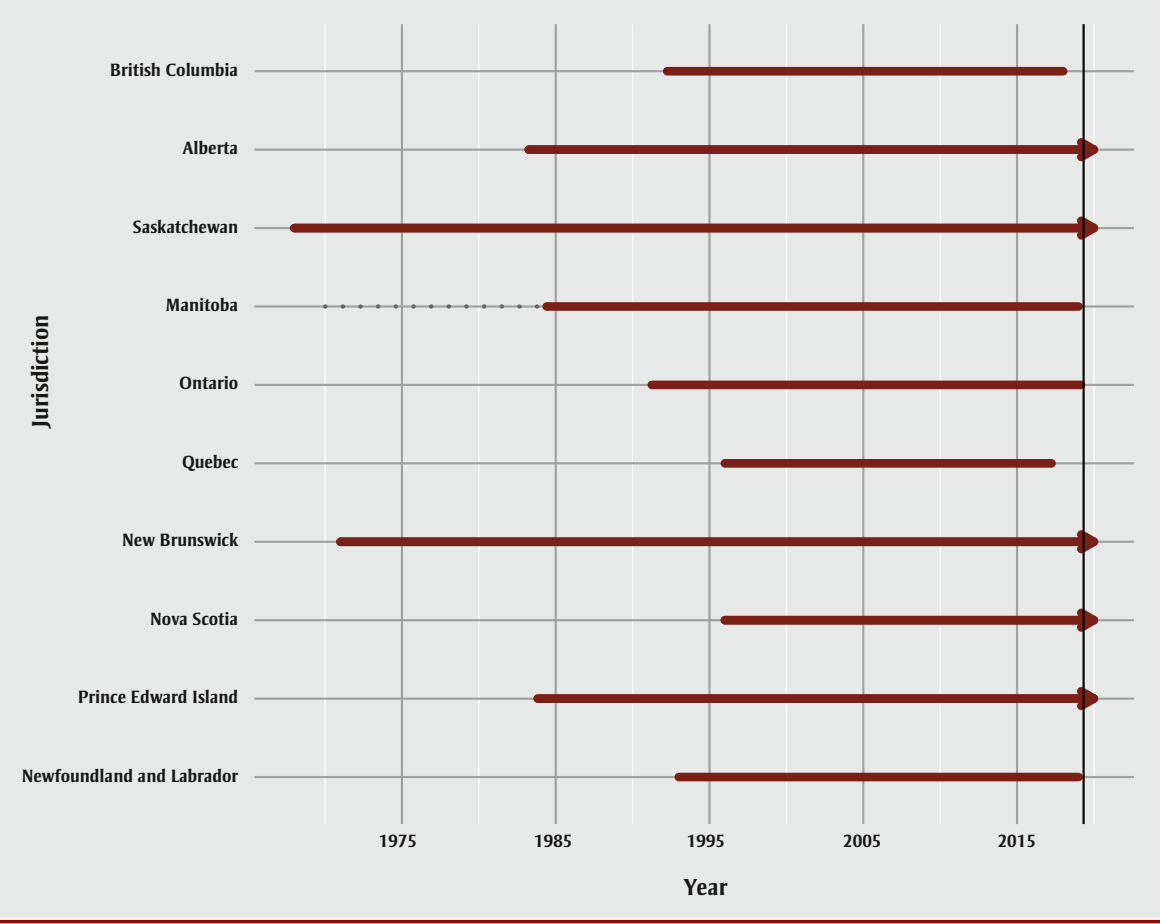

Notes: Arrows indicate registry data are continually updated daily or weekly and data are available as of the last update. Dotted gray line indicates data availability may be limited. Vertical black line indicates date of survey administration (i.e. April 2019). Dates of data availability are current as of survey response date (May 2019); updates may be available after this date.

file to preserve the registry data at that point in time) of their registries are regularly saved and stored.

\section{Start and end of coverage}

Table 1 summarizes the responses provided around start and end dates of health insurance coverage for individuals. There was heterogeneity across the reporting jurisdictions on the capture of information about mobility of health-insured residents (i.e. where an individual moved to when leaving the jurisdiction and where they moved from when entering the jurisdiction). For most jurisdictions, individuals were added to the registry three months after moving into the jurisdiction and flagged for end of coverage three months after moving out of the jurisdiction. The timeline for being added to the registry and being flagged for end of coverage in cases of birth and death were variable across jurisdictions. There was substantial diversity in the end-of-coverage cancellation codes (e.g. deceased, left country, duplicate record) provided by the key informants; only Ontario indicated no end-of-coverage codes were available. While data quality checks for start and end of coverage were implemented in a number of jurisdictions (i.e. British Columbia, Alberta, Saskatchewan, Ontario, Quebec, Nova Scotia and Newfoundland and Labrador), key informants did not always have information about data quality assessment processes or did not report that data quality assessments were undertaken.

\section{Population characteristics and attributes captured}

All jurisdictions reported that their registries contained a primary address, birth date and sex for health-insured residents (Table 2).

A family unit identifier, that is, a code to indicate familial relationships, was reported for Alberta, Saskatchewan, Manitoba, New Brunswick and the Northwest Territories. Prince Edward Island reported having a household identifier, but noted limitations in its use (e.g. individuals in a group home have the same household identifier). British Columbia indicated that familial relationships among residents could be ascertained from other administrative data sources. Family relationship codes (i.e. indication of relationships among residents, such as parent, offspring, spouse or sibling) were available in Alberta, Saskatchewan, Manitoba and New Brunswick.

Only Ontario reported having information about ethnicity in its health insurance registry. Identifiable categories for ethnicity were general, Chinese and South Asian. These categories are derived from an algorithm applied to the data and not directly collected.

Measures of socioeconomic status (e.g. income quintile) were available in the health insurance registries of Ontario and Quebec; Ontario's measure was algorithmdriven. British Columbia indicated socioeconomic status could be determined for a subset of individuals by linking to a supplementary database.

Lastly, place of birth was available in Alberta and Prince Edward Island, although other jurisdictions did note that linkage of registry data with other sources could aid in identifying this information.

\section{Population identification}

Table 3 provides information about the populations identifiable in health insurance registries. All jurisdictions indicated they could identify at least some of the populations in question, except for Quebec. Quality of population identifiers was heterogeneous. For example, the First Nations identifier in Manitoba's health insurance registry may result in misclassification of individuals, because it is based on selfreport. This means that a First Nations individual would only be flagged as such if that individual disclosed this information to insurance registry staff. In Alberta, the federal government had previously verified First Nations status, but stopped when Alberta eliminated health insurance premiums in 2009. To aid in preserving data quality, Alberta has maintained the flag for those present prior to the change, and any offspring are conferred unofficial status for reporting purposes. However, misclassification may still occur.

\section{Discussion}

The results of this survey provide important insights about the data contained within health insurance registries across Canada (i.e. 10 provinces and the Northwest Territories). Health insurance registry data go back as far as 1968 (in the case of Saskatchewan). All reporting jurisdictions had data going back to at least 1996. 
TABLE 1

Start and end of individual coverage information in provincial/territorial health insurance registries, Canada, 2019

\begin{tabular}{|c|c|c|c|c|c|c|c|c|c|c|c|}
\hline $\begin{array}{l}\text { Start and end of } \\
\text { coverage }\end{array}$ & $\begin{array}{l}\text { British } \\
\text { Columbia }\end{array}$ & Alberta & Saskatchewan & Manitoba & Ontario & Quebec & $\begin{array}{c}\text { New } \\
\text { Brunswick }\end{array}$ & Nova Scotia & $\begin{array}{l}\text { Prince Edward } \\
\text { Island }\end{array}$ & $\begin{array}{c}\text { Newfoundland } \\
\text { and Labrador }\end{array}$ & $\begin{array}{l}\text { Northwest } \\
\text { Territories }\end{array}$ \\
\hline \multicolumn{12}{|c|}{ For residents moving into jurisdiction: } \\
\hline $\begin{array}{l}\text { Where the individual } \\
\text { moved from }\end{array}$ & No & Yes & Yes & Yes & No & No & Yes & Yes & Yes & $\begin{array}{l}\text { Yes, if within } \\
\text { Canada }\end{array}$ & NR \\
\hline $\begin{array}{l}\text { Length of time after } \\
\text { moving that newcomers } \\
\text { (from within Canada) } \\
\text { are added to registry }\end{array}$ & 3 months & $\begin{array}{l}\text { Added } \\
\text { immediately but } \\
\text { must live in } A B \\
\text { for } 3 \text { months } \\
\text { before eligible }\end{array}$ & $\begin{array}{l}3 \text { months (i.e. first } \\
\text { of the third month } \\
\text { after arrival) }\end{array}$ & $\begin{array}{l}\text { Added once } \\
\text { applied for but } \\
\text { must live in MB } \\
\text { for } 3 \text { months (i.e. } \\
\text { first day of full } \\
\text { third month) } \\
\text { before eligible }^{\mathrm{b}}\end{array}$ & 3 months & 3 months & 90 days & 3 months & 3 months & 3 months & NR \\
\hline $\begin{array}{l}\text { Length of time after } \\
\text { moving until } \\
\text { immigrants are added } \\
\text { to registry }\end{array}$ & 3 months & Varies & Varies & Unsure & 3 months & 3 months & 90 days $^{\mathrm{c}}$ & Date of arrival & $\begin{array}{l}\text { First day of arrival } \\
\text { or first day } \\
\text { granted } \\
\text { permanent } \\
\text { residence, } \\
\text { whichever is later }\end{array}$ & Date of arrival & NR \\
\hline \multicolumn{12}{|c|}{ For residents moving out of jurisdiction: } \\
\hline $\begin{array}{l}\text { Where the individual } \\
\text { moved to }\end{array}$ & No & Yes & $\begin{array}{l}\text { Yes, if within } \\
\text { Canada }\end{array}$ & Yes & No & No & $\begin{array}{l}\text { Yes, if within } \\
\text { Canada }\end{array}$ & Yes & $\begin{array}{l}\text { Yes, if within } \\
\text { Canada }\end{array}$ & No & NR \\
\hline $\begin{array}{l}\text { Length of time after } \\
\text { moving that residents } \\
\text { are flagged for end of } \\
\text { coverage }^{\mathrm{a}}\end{array}$ & $\begin{array}{l}\text { Until residents } \\
\text { submit request } \\
\text { of cancellation }\end{array}$ & $\begin{array}{l}\text { When coverage } \\
\text { begins in the } \\
\text { new province, } \\
\text { OR the day they } \\
\text { leave the country }\end{array}$ & $\begin{array}{l}3 \text { months (i.e. } \\
\text { covered for } \\
\text { remainder of } \\
\text { month of } \\
\text { departure plus } 2 \\
\text { more months) }\end{array}$ & $\begin{array}{l}3 \text { months (i.e. } \\
\text { covered for } \\
\text { remainder of } \\
\text { month of departure } \\
\text { plus } 2 \text { more } \\
\text { months) for } \\
\text { Canadian citizens } \\
\text { and permanent } \\
\text { residents. Day of } \\
\text { permanent move } \\
\text { for work and study } \\
\text { permit holders }\end{array}$ & $\begin{array}{l}\text { Unclear from } \\
\text { the data }\end{array}$ & 3 months & $\begin{array}{l}\text { When coverage } \\
\text { begins in the } \\
\text { new province } \\
\text { OR when NB } \\
\text { Medicare is } \\
\text { notified they } \\
\text { left the country }\end{array}$ & 3 months & $\begin{array}{l}\text { The day before } \\
\text { coverage begins } \\
\text { in the new } \\
\text { province }\end{array}$ & 3 months & NR \\
\hline
\end{tabular}

Continued on the following page 
TABLE 1 (continued)

Start and end of individual coverage information in provincial/territorial health insurance registries, Canada, 2019

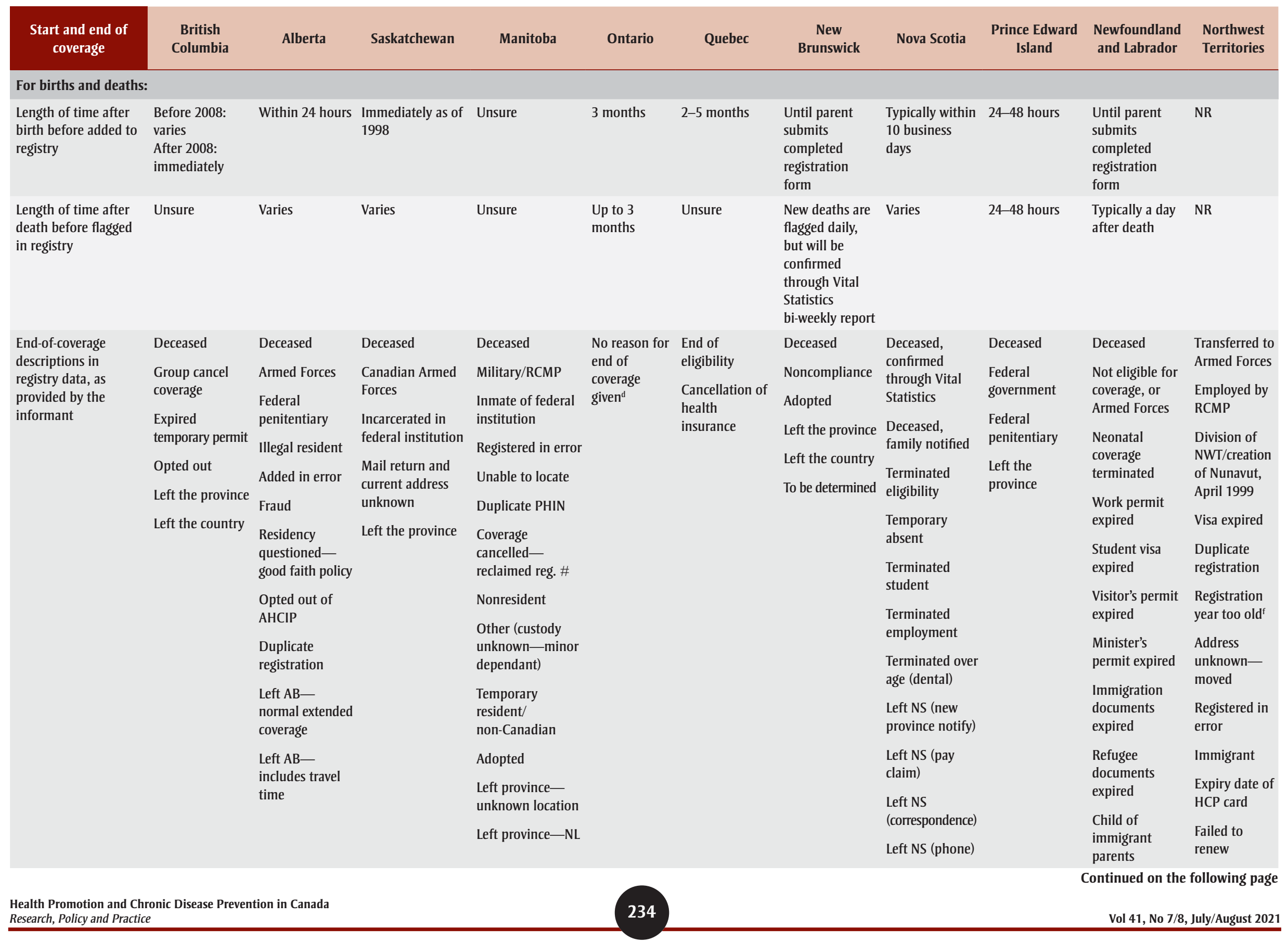


TABLE 1 (continued)

Start and end of individual coverage information in provincial/territorial health insurance registries, Canada, 2019

\begin{tabular}{|c|c|c|c|c|c|c|c|c|c|c|c|}
\hline $\begin{array}{l}\text { Start and end of } \\
\text { coverage }\end{array}$ & $\begin{array}{c}\text { British } \\
\text { Columbia }\end{array}$ & Alberta & Saskatchewan & Manitoba & Ontario & Quebec & $\begin{array}{c}\text { New } \\
\text { Brunswick }\end{array}$ & Nova Scotia & $\begin{array}{l}\text { Prince Edward } \\
\text { Island }\end{array}$ & $\begin{array}{l}\text { Newfoundland } \\
\text { and Labrador }\end{array}$ & $\begin{array}{l}\text { Northwest } \\
\text { Territories }\end{array}$ \\
\hline & & $\begin{array}{l}\text { Left } \mathrm{AB} \text { - } \\
\text { circumstances } \\
\text { unknown } \\
\text { Left } \mathrm{AB} \text { - } \\
\text { notified by } \\
\text { other provincial } \\
\text { health office } \\
\text { Left Canada } \\
\text { Left Canada- } \\
\text { maximum three } \\
\text { months } \\
\text { Left Canada- } \\
\text { coverage } \\
\text { extended } \\
1 \text { month } \\
\text { Left Canada- } \\
\text { coverage } \\
\text { extended } \\
3 \text { months } \\
\text { Other }\end{array}$ & & $\begin{array}{l}\text { Left province-PEI } \\
\text { Left province-NB } \\
\text { Left province-NS } \\
\text { Left province-QC } \\
\text { Left province-ON } \\
\text { Left province-SK } \\
\text { Left province-AB } \\
\text { Left province-BC } \\
\text { Left province-YT } \\
\text { Left province- } \\
\text { NWT } \\
\text { Left province-NU } \\
\text { Left province- } \\
\text { USA } \\
\text { Left province- } \\
\text { other country }\end{array}$ & & & & & & $\begin{array}{l}\text { Out of province } \\
\text { coverage } \\
\text { Inactive }^{\mathrm{e}} \\
\text { Left the province } \\
\text { Left the province } \\
\text { and under } \\
\text { social services }\end{array}$ & $\begin{array}{l}\text { HCP card } \\
\text { unclaimed/ } \\
\text { undeliverable } \\
\text { mail } \\
\text { NWT inmate } \\
\text { released } \\
\text { Coverage } \\
\text { suspended } \\
\text { Address box } \\
\text { closed } \\
\text { Address } \\
\text { incomplete } \\
\text { No such } \\
\text { address }\end{array}$ \\
\hline
\end{tabular}

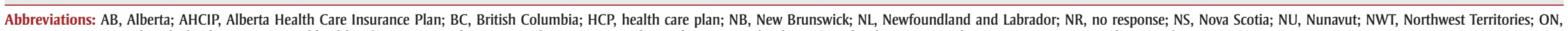
Ontario; PEI, Prince Edward Island; PHIN, personal health information number; QC, Quebec; RCMP, Royal Canadian Mounted Police; SK, Saskatchewan; YT, Yukon Territory; USA, United States of America.

${ }^{a}$ Criteria for "3 months" varies among jurisdictions. Specifications added where jurisdictions provided information.

${ }^{\mathrm{b}}$ For Canadian citizens and permanent residents. For work permit holders and their dependants coming to Manitoba from another Canadian jurisdiction, coverage begins on the date of arrival if they provide proof of arrival date.

' Date of arrival for refugees.

d End-of-coverage codes are captured by the Ontario Ministry of Health, but are not available to the research data holders at ICES.

${ }^{\mathrm{e}}$ No activity on medical care plan.

${ }^{\mathrm{f}}$ Year of registration indicates health coverage has expired. 
TABLE 2

Population characteristics and attributes captured in provincial/territorial health insurance registries, Canada, 2019

\begin{tabular}{|c|c|c|c|c|c|c|c|c|c|c|c|}
\hline $\begin{array}{c}\text { Population } \\
\text { characteristics }\end{array}$ & $\begin{array}{c}\text { British } \\
\text { Columbia }\end{array}$ & Alberta & Saskatchewan & Manitoba & Ontario $^{b}$ & Quebec & $\begin{array}{c}\text { New } \\
\text { Brunswick }^{c}\end{array}$ & Nova Scotia & $\begin{array}{l}\text { Prince Edward } \\
\text { Island }\end{array}$ & $\begin{array}{l}\text { Newfoundland } \\
\text { and Labrador }\end{array}$ & $\begin{array}{l}\text { Northwest } \\
\text { Territories }\end{array}$ \\
\hline \multicolumn{12}{|l|}{ Residence } \\
\hline Primary address & Yes & Yes & Yes & Yes & Yes & Yes & Yes & Yes & Yes & Yes & Yes \\
\hline $\begin{array}{l}\text { Previous address } \\
\text { available? }\end{array}$ & Yes & Yes & Yes & No & Yes & Yes & Yes & No & Yes & Yes & Yes \\
\hline \multicolumn{12}{|l|}{ Date of birth } \\
\hline Date of birth & Yes & Yes & Yes & Yes & Yes & Yes & Yes & Yes & Yes & Yes & Yes \\
\hline \multicolumn{12}{|l|}{ Sex } \\
\hline Sex & Yes & Yes & Yes & Yes & Yes & Yes & Yes & Yes & Yes & Yes & Yes \\
\hline $\begin{array}{l}\text { New classifications } \\
\text { implemented }^{d}\end{array}$ & No & No & No & No & No & No & Yes & Yes & No & Yes & NR \\
\hline \multicolumn{12}{|l|}{ Familial relationships } \\
\hline Family unit identifier & $\begin{array}{l}\text { No, but can } \\
\text { link to other } \\
\text { databases to } \\
\text { determine }\end{array}$ & Yes & Yes & Yes & No & No & Yes & No & Yes $^{e}$ & No & Yes \\
\hline $\begin{array}{l}\text { Relationships } \\
\text { available }\end{array}$ & $\mathrm{N} / \mathrm{A}$ & Family unit & $\begin{array}{l}\text { Head of family } \\
\text { (max } 2 \text { per family) } \\
\text { and dependents }\end{array}$ & $\begin{array}{l}\text { Family unit containing } \\
\text { registrant, and if } \\
\text { applicable, spouse and } \\
\text { dependents }\end{array}$ & $\mathrm{N} / \mathrm{A}$ & $\mathrm{N} / \mathrm{A}$ & $\begin{array}{l}\text { Head of } \\
\text { household } \\
\text { identifier }\end{array}$ & N/A & NR & $\mathrm{N} / \mathrm{A}$ & NR \\
\hline Relationship coding & $\mathrm{N} / \mathrm{A}$ & $\begin{array}{l}\text { Family units are grouped } \\
\text { together under a single } \\
\text { account number } \\
\text { Specific relationships } \\
\text { codes: } \\
\text { Unknown; } \\
\text { Subscriber; } \\
\text { Spouse; } \\
\text { Dependent aged < } 21 \text { yrs; } \\
\text { Student aged } 20 \text { yrs, } \\
8 \text { months to } 25 \text { yrs; } \\
\text { Permanent dependent } \\
\text { due to mental/physical } \\
\text { infirmity; } \\
\text { Student status under } \\
\text { review }\end{array}$ & $\begin{array}{l}\text { All members have } \\
\text { the same family } \\
\text { number and } \\
\text { individuals are } \\
\text { listed as either } \\
\text { head of family or } \\
\text { dependent }\end{array}$ & $\begin{array}{l}\text { All family members } \\
\text { residing in MB are } \\
\text { assigned the same MB } \\
\text { health registration number } \\
\text { Specific relationships are } \\
\text { indicated by number } \\
\text { (from 0-8) for the } \\
\text { following: } \\
\text { purged or non res; } \\
\text { family head; } \\
\text { legal spouse; } \\
\text { common law spouse; } \\
\text { child; } \\
\text { stepchild; } \\
\text { incapacitated child; } \\
\text { grandchild }\end{array}$ & $\mathrm{N} / \mathrm{A}$ & $\mathrm{N} / \mathrm{A}$ & $\begin{array}{l}\text { There is a } \\
\text { "Head of } \\
\text { Household" } \\
\text { ID that can be } \\
\text { linked to all } \\
\text { family } \\
\text { members }\end{array}$ & $\mathrm{N} / \mathrm{A}$ & $\mathrm{N} / \mathrm{A}$ & $\mathrm{N} / \mathrm{A}$ & NR \\
\hline
\end{tabular}


TABLE 2 (continued)

Population characteristics and attributes captured in provincial/territorial health insurance registries, Canada, 2019

\begin{tabular}{|c|c|c|c|c|c|c|c|c|c|c|c|}
\hline $\begin{array}{c}\text { Population } \\
\text { characteristics }\end{array}$ & $\begin{array}{c}\text { British } \\
\text { Columbia }^{a}\end{array}$ & Alberta & Saskatchewan & Manitoba & Ontario $^{b}$ & Quebec & $\begin{array}{c}\text { New } \\
\text { Brunswick }\end{array}$ & Nova Scotia & $\begin{array}{l}\text { Prince Edward } \\
\text { Island }\end{array}$ & $\begin{array}{l}\text { Newfoundland } \\
\text { and Labrador }\end{array}$ & $\begin{array}{l}\text { Northwest } \\
\text { Territories }\end{array}$ \\
\hline \multicolumn{12}{|l|}{ Ethnicity } \\
\hline Ethnicity & No & No & No & No & Yes & No & No & No & No & No & No \\
\hline $\begin{array}{l}\text { Identifiable } \\
\text { ethnicities }\end{array}$ & $\mathrm{N} / \mathrm{A}$ & $\mathrm{N} / \mathrm{A}$ & $\mathrm{N} / \mathrm{A}$ & $\mathrm{N} / \mathrm{A}$ & $\begin{array}{l}\text { Generalf, } \\
\text { Chinese, } \\
\text { South Asian }\end{array}$ & $\mathrm{N} / \mathrm{A}$ & $\mathrm{N} / \mathrm{A}$ & $\mathrm{N} / \mathrm{A}$ & $\mathrm{N} / \mathrm{A}$ & $\mathrm{N} / \mathrm{A}$ & $\mathrm{N} / \mathrm{A}$ \\
\hline \multicolumn{12}{|l|}{ Socioeconomic status } \\
\hline SES available & $\begin{array}{l}\text { No, but can } \\
\text { link for a } \\
\text { subset to } \\
\text { determine }\end{array}$ & No & No & No & Yes & Yes & No & No & No & No & No \\
\hline $\begin{array}{l}\text { Information used to } \\
\text { define SES }\end{array}$ & $\mathrm{N} / \mathrm{A}$ & $\mathrm{N} / \mathrm{A}$ & $\mathrm{N} / \mathrm{A}$ & $\mathrm{N} / \mathrm{A}$ & Income & Other $^{8}$ & $\mathrm{~N} / \mathrm{A}$ & $\mathrm{N} / \mathrm{A}$ & $\mathrm{N} / \mathrm{A}$ & $\mathrm{N} / \mathrm{A}$ & $\mathrm{N} / \mathrm{A}$ \\
\hline SES coding & $\mathrm{N} / \mathrm{A}$ & $\mathrm{N} / \mathrm{A}$ & $\mathrm{N} / \mathrm{A}$ & $\mathrm{N} / \mathrm{A}$ & $\begin{array}{l}1,2,3,4,5 \\
\text { (quintiles) }\end{array}$ & $\begin{array}{l}\text { Deprivation } \\
\text { index }\end{array}$ & $\mathrm{N} / \mathrm{A}$ & $\mathrm{N} / \mathrm{A}$ & $\mathrm{N} / \mathrm{A}$ & $\mathrm{N} / \mathrm{A}$ & $\mathrm{N} / \mathrm{A}$ \\
\hline \multicolumn{12}{|l|}{ Place of birth } \\
\hline Place of birth & No & Yes & No & No & No & No & No & $\begin{array}{l}\text { No; can link to } \\
\text { other databases/ } \\
\text { sources to } \\
\text { determine if } \\
\text { born in NS }\end{array}$ & Yes & $\begin{array}{l}\text { No; can link } \\
\text { to other } \\
\text { databases/ } \\
\text { sources to } \\
\text { determine if } \\
\text { born in NL }\end{array}$ & NR \\
\hline Coding & $\mathrm{N} / \mathrm{A}$ & Structured text field & $\mathrm{N} / \mathrm{A}$ & $\mathrm{N} / \mathrm{A}$ & $\mathrm{N} / \mathrm{A}$ & $\mathrm{N} / \mathrm{A}$ & $\mathrm{N} / \mathrm{A}$ & $\mathrm{N} / \mathrm{A}$ & $\begin{array}{l}\text { Country/ } \\
\text { province }\end{array}$ & $\mathrm{N} / \mathrm{A}$ & NR \\
\hline
\end{tabular}

Abbreviations: BC, British Columbia; MB, Manitoba; N/A, not applicable; NL, Newfoundland and Labrador; NR, no response; NS, Nova Scotia; RCMP, Royal Canadian Mounted Police; SES, socioeconomic status.

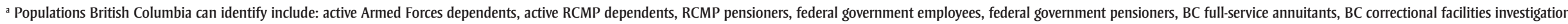
unit, and First Nations.

${ }^{\mathrm{b}}$ All "yes" responses are obtained by linking to other databases; data are not directly available in registry.

'New Brunswick is officially bilingual (English and French). Therefore, language data are also captured in the registry.

" "New classifications implemented" refers to including an additional nonbinary option in addition to the "Male" and "Female" classifications.

${ }^{\mathrm{e}}$ Household identifier.

${ }^{\mathrm{f}}$ Individuals not included in the Chinese or South Asian category are included in the General category.

${ }^{8}$ SES is determined using a material and social deprivation index, which is assigned based on geographical location. 
TABLE 3

Population identification information in provincial/territorial health insurance registries, Canada, 2019

\begin{tabular}{|c|c|c|c|c|c|c|c|c|c|c|c|}
\hline $\begin{array}{c}\text { Population } \\
\text { identification }\end{array}$ & $\begin{array}{c}\text { British } \\
\text { Columbia }^{a}\end{array}$ & Alberta & Saskatchewan & Manitoba & Ontario $^{j}$ & Quebec & $\begin{array}{c}\text { New } \\
\text { Brunswick }^{\mathrm{k}}\end{array}$ & Nova Scotia & $\begin{array}{l}\text { Prince Edward } \\
\text { Island }\end{array}$ & $\begin{array}{c}\text { Newfoundland } \\
\text { and Labrador }\end{array}$ & $\begin{array}{l}\text { Northwest } \\
\text { Territories }\end{array}$ \\
\hline \multicolumn{12}{|l|}{ Population } \\
\hline $\begin{array}{l}\text { Full-time members of } \\
\text { the Canadian Armed } \\
\text { Forces }\end{array}$ & NR & Yes & Yes $^{d}$ & Yes $^{8}$ & No & No & Yes' & $\mathrm{No}^{\circ}$ & No & No & NR \\
\hline $\begin{array}{l}\text { Part-time members of } \\
\text { the Canadian Armed } \\
\text { Forces }\end{array}$ & NR & No & Yes $^{d}$ & Yes $^{8}$ & No & No & No & No & No & No & NR \\
\hline Veterans & No & Yes & No & NR & No & No & No & $\mathrm{No}^{\circ}$ & No & No & NR \\
\hline $\begin{array}{l}\text { Royal Canadian } \\
\text { Mounted Police }\end{array}$ & No & Yes & No & Yes & No & No & Yes & $\mathrm{No}^{\circ}$ & No & No & NR \\
\hline $\begin{array}{l}\text { Federal penitentiary } \\
\text { inmates }\end{array}$ & NR & Yes & Yes $^{\mathrm{e}}$ & Yes $^{\mathrm{h}}$ & No & No & No & No & Yes & No & NR \\
\hline $\begin{array}{l}\text { Provincial peniten- } \\
\text { tiary inmates }\end{array}$ & Yes & Yes $^{b}$ & Yes & NR & No & No & Yes & No & No & No & NR \\
\hline $\begin{array}{l}\text { First Nations on } \\
\text { reserve }\end{array}$ & NR & Yes $^{b}$ & Yes $^{f}$ & Yesi & Yes & No & $\mathrm{No}^{\mathrm{m}}$ & No & No & No & Yes \\
\hline $\begin{array}{l}\text { First Nations off } \\
\text { reserve }\end{array}$ & NR & Yes $^{b}$ & Yes $^{f}$ & Yesi & Yes & No & $\mathrm{No}^{\mathrm{m}}$ & No & No & No & Yes \\
\hline Inuit & No & Yes $^{b}$ & No & NR & Yes & No & No & No & No & No & Yes \\
\hline Métis & No & $\mathrm{No}^{\mathrm{c}}$ & No & NR & Yes & No & No & No & No & No & Yes \\
\hline \multicolumn{12}{|c|}{ Nonpermanent residents } \\
\hline Refugee claimants & Yes & Yes & Yes & NR & Yes & No & No & No & Yes & $\begin{array}{l}\text { Yes, upon } \\
\text { termination of } \\
\text { coverage }\end{array}$ & NR \\
\hline $\begin{array}{l}\text { Persons with a } \\
\text { study permit }\end{array}$ & No & Yes & Yes & NR & No & No & Yes & Yes & Yes & $\begin{array}{l}\text { Yes, upon } \\
\text { termination of } \\
\text { coverage }\end{array}$ & NR \\
\hline $\begin{array}{l}\text { Persons with a } \\
\text { work permit }\end{array}$ & No & Yes & Yes & NR & No & No & No & Yes & Yes & $\begin{array}{l}\text { Yes, upon } \\
\text { termination of } \\
\text { coverage }\end{array}$ & NR \\
\hline
\end{tabular}

Continued on the following page 
TABLE 3 (continued)

Population identification information in provincial/territorial health insurance registries, Canada, 2019

\begin{tabular}{|c|c|c|c|c|c|c|c|c|c|c|c|}
\hline $\begin{array}{l}\text { Population } \\
\text { identification }\end{array}$ & $\begin{array}{c}\text { British } \\
\text { Columbia }^{a}\end{array}$ & Alberta & Saskatchewan & Manitoba & Ontario $^{j}$ & Quebec & $\begin{array}{c}\text { New } \\
\text { Brunswick }^{k}\end{array}$ & Nova Scotia & $\begin{array}{l}\text { Prince Edward } \\
\text { Island }\end{array}$ & $\begin{array}{c}\text { Newfoundland } \\
\text { and Labrador }\end{array}$ & $\begin{array}{l}\text { Northwest } \\
\text { Territories }\end{array}$ \\
\hline \multicolumn{12}{|l|}{ Immigrants } \\
\hline Landed immigrants & NR & Yes & Yes & NR & Yes & No & Yes $^{\mathrm{n}}$ & Yes & Yes & $\begin{array}{l}\text { Yes, upon } \\
\text { termination of } \\
\text { coverage }\end{array}$ & NR \\
\hline \multicolumn{12}{|l|}{ Permanent residents } \\
\hline Economic immigrants & No & No & No & NR & Yes & No & No & No & Yes & No & NR \\
\hline $\begin{array}{l}\text { Family members of } \\
\text { permanent residents }\end{array}$ & NR & Yes & No & NR & No & No & No & No & Yes & No & NR \\
\hline
\end{tabular}

Abbreviations: BC, British Columbia; FN, First Nations; MB, Manitoba; NB, New Brunswick; NR, no response; RCMP, Royal Canadian Mounted Police; SK, Saskatchewan.

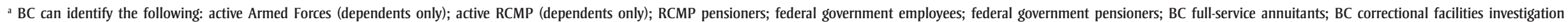
unit; First Nations individuals.

${ }^{\mathrm{b}}$ Active capture of this flag was discontinued in January 2009.

' Can link to database to determine for analytic purposes.

${ }^{\mathrm{d}}$ There is no distinction between part-time and full-time members of the Armed Forces.

${ }^{\mathrm{e}}$ Only flagged if covered by SK prior to incarceration.

${ }^{\mathrm{f}}$ Flagged if self-identified as FN. Residence or correspondence address or both can be used to determine if on or off reserve; however, many addresses can be ambiguous for on vs. off reserve.

${ }^{8}$ There is no distinction between part-time and full-time members of the Armed Forces.

h Can only see whose coverage was cancelled for the reason "Code 8-Inmate of Federal Institution."

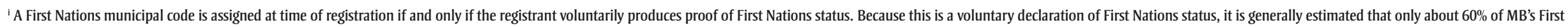
Nations population is identified as First Nations in Manitoba Health's registry population.

j For all "yes" responses, data are obtained by linking registry data to other databases; data are not directly available in registry.

${ }^{k} \mathrm{NB}$ is officially bilingual (English and French). Therefore, language data are captured in the registry.

' Some full-time members are identified, but not all.

${ }^{\mathrm{m}}$ As of February 2020, New Brunswick Department of Health is working with First Nations on the creation of a First Nations identifier

${ }^{\mathrm{n}}$ Landed immigrants and permanent residents are not differentiated in the NB medicare system.

${ }^{\circ}$ Only recorded if self-identified. Not a reliable source of population identification, as this information is not comprehensive. 
Individuals moving in or out of the jurisdiction are generally added or flagged for end of coverage three months after moving; timelines are more variable for beginning or ending of coverage due to births and deaths. Events recorded for end of coverage differ among jurisdictions. All jurisdictions record a primary address, date of birth and sex. Family identifiers, ethnicity, socioeconomic status and place of birth are recorded in select jurisdictions. Ability to identify members of certain populations, such as First Nations, the Canadian Armed Forces and inmates of federal penitentiaries, is variable across jurisdictions.

Previous research has compared data contained in physician services databases across Canada. ${ }^{16}$ However, there has been limited research on provincial and territorial health insurance registry data and its quality. Publications on registry data have reported on Manitoba's and British Columbia's health insurance registries. ${ }^{9,11,17}$ However, the most recent Manitoban publication was in 1999, ${ }^{9}$ and British Columbia's paper focussed on the development of a research registry to which the provincial health insurance registry contributed. ${ }^{17}$ Tang et al. ${ }^{18}$ reported on ethnic classifications available in Canadian health insurance registries and found that flags only existed on First Nations people in the registries. In contrast, we found that Ontario had flags derived from an algorithm for subpopulations of South Asian and Chinese descent. A systematic review conducted by Hinds et al. ${ }^{13}$ did not identify any studies that had investigated the quality of health insurance registry information.

Capture of population characteristics and attributes allows for surveillance measures to be stratified by potential risk factors (e.g. social determinants of health such as socioeconomic status, immigration status and ethnicity). Results reported here help summarize the jurisdictions that are suitable for these analyses. However, heterogeneity among jurisdictions in population identification also has implications for who is included in the CCDSS estimates, and suggests that inclusions and exclusions may not be consistent across jurisdictions.

A major value of the health insurance registry comes from preserving snapshots, or timestamped records, of registry data. ${ }^{9}$ Our study results indicate that over 20 years of registry data are available in all reporting jurisdictions, with snapshots available to capture changes in the registry. There are challenges associated with using health insurance registries for longitudinal studies: health insurance registries are not static, registry data and data quality change over time, and older data are not always linkable. Nonetheless, the benefits of being able to use these data to conduct longitudinal cohort and intergenerational studies with minimal cost and data collection far outweigh the challenges.

\section{Strengths and limitations}

This study is unique in providing insights about the data contained within health insurance registries across Canada using a standardized survey with near complete coverage of the provinces and territories. Surveys were completed by individuals with in-depth knowledge of the registry data and access to other informants to provide additional information if needed.

However, there are some limitations. Our study did not employ a validated survey for information capture, as no such survey exists. This hinders international comparisons. As well, health insurance registries are complex databases, and it is not possible to capture all nuances of their features in a survey conducted at a single point in time. Not all elements collected during the registration process will be available to potential data users. Many of these elements are administrative in nature. Many systems are dynamic, being continually updated, so extracts or snapshots are created with a methodology to provide the most accurate and consistent view of the population.

\section{Future research}

Future studies could be undertaken to validate key population characteristics included in health insurance registry data, including dates of birth and death, coverage cancellation codes, location of residence and identifiers for specific populations. Another research opportunity lies in assessing the timeliness of characteristic updates. However, a key challenge with such studies is identifying and accessing appropriate population-based validation data sources that can be linked to health insurance registration data. While vital statistics data could be used to assess the accuracy of dates of birth and death, validation data sources for other key population characteristics may not be readily available in all jurisdictions.

Previous studies have compared aggregate population counts obtained from health insurance registries to counts from Statistics Canada census data. ${ }^{19,20}$ However, potential sources of inaccuracies were not determined. Therefore, future research could look at potential sources of discrepancy between population counts in registry and census data, and estimate the impact of these discrepancies on health measures.

Exploring changes in health insurance registration coverage over time is another potential area of future research. Registries are not static; exclusions may not be consistent over time. Comprehensive information about changes in the data can help ensure accuracy of health trend estimates.

Future research should investigate the feasibility of a common data framework, such as the Generalized Data Model proposed by Danese et al. ${ }^{21}$ to facilitate the systematic and standardized capture of information in health insurance registries. However, access to some registry data elements may be subject to privacy legislation, and data are primarily collected for administrative, not research, purposes. This could lead to challenges in implementing a common data framework.

Finally, there is a potential role for a national organization to facilitate the harmonization or standardization of data in health insurance registries. Examples of such organizations include the Canadian Institute for Health Information, which has recently proposed standards for collecting data on patient ethnicity, ${ }^{22}$ and Health Data Research Network Canada, which aims to support multi-jurisdiction studies by connecting and establishing research data infrastructure. ${ }^{23}$

\section{Acknowledgements}

This work was made possible through collaboration between PHAC and the respective provincial and territorial governments of British Columbia, Alberta, Saskatchewan, Manitoba, Ontario, Quebec, New Brunswick, Nova Scotia, Prince Edward Island, Newfoundland and Labrador and Yukon. No endorsement by the provinces and territories is intended or should be inferred. 


\section{Conflicts of interest}

The authors have no conflicts of interest to declare.

\section{Authors' contributions and statement}

$\mathrm{NCH}$ and LML drafted the manuscript and all authors contributed to its revisions. LML, CR, JE, SO, LM and KH defined the scope of the survey. NCH, LML, CR, JE, SO, LM and $\mathrm{KH}$ developed the survey. LML and NCH contacted key informants and collected completed surveys. LR, KAMP, MA, MS, RP, MM, AY, JS, YL, LWS, FS, AA, BZ and JA reviewed the manuscript for accuracy and ensured appropriate interpretation of health registry data.

The content and views expressed in this article are those of the authors and do not necessarily reflect those of the Government of Canada.

\section{References}

1. LeBlanc AG, Gao YJ, McRae L, Pelletier C. At-a-glance-Twenty years of diabetes surveillance using the Canadian Chronic Disease Surveillance System. Health Promot Chronic Dis Prev Can. 2019;39(11):306-9.

2. Robitaille C, Dai S, Waters C, et al. Diagnosed hypertension in Canada: incidence, prevalence and associated mortality. CMAJ. 2012;184(1):E49-E56. https://doi.org/10.1503/cmaj.101863

3. Robitaille C, Bancej C, Dai S, et al. Surveillance of ischemic heart disease should include physician billing claims: population-based evidence from administrative health data across seven Canadian provinces. BMC Cardiovasc Disord. 2013;13:88. https://doi.org/10 $.1186 / 1471-2261-13-88$

4. Blais C, Dai S, Waters C, et al. Assessing the burden of hospitalized and community-care heart failure in Canada. Can J Cardiol. 2014;30(3):352-8. https:// doi.org/10.1016/j.cjca.2013.12.013

5. Blais C, Jean S, Sirois C, et al. Quebec Integrated Chronic Disease Surveillance System (QICDSS), an innovative approach. Chronic Dis Inj Can. 2014; 34(4):226-35.
6. Gershon AS, Guan J, Wang C, To T. Trends in asthma prevalence and incidence in Ontario, Canada, 1996-2005: a population study. Am J Epidemiol. 2010;172(6):728-36. https://doi.org /10.1093/aje/kwq189

7. Hux JE, Ivis F, Flintoft V, Bica A. Diabetes in Ontario: determination of prevalence and incidence using a validated administrative data algorithm. Diabetes Care. 2002;25(3):512-6. https:// doi.org/10.2337/diacare.25.3.512

8. Lix L, Ayles J, Bartholomew S, et al The Canadian Chronic Disease Surveillance System: a model for collaborative surveillance. Int J Popul Data Sci. 2018;3(3):433. https://doi.org/10.23889 /ijpds.v3i3.433

9. Roos LL, Nicol JP. A research registry: uses, development, and accuracy. J Clin Epidemiol. 1999;52(1):39-47. https:// doi.org/10.1016/s0895-4356(98) 00126-7

10. Health Canada. Canada's health care system [Internet]. Ottawa (ON): Government of Canada; 2011 May [cited 2020 Jul 23]. Available from: https://www canada.ca/en/health-canada/services /health-care-system/reports-publications /health-care-system/canada.html

11. Roos LL, Mustard CA, Nicol JP, et al. Registries and administrative data: organization and accuracy. Med Care. 1993;31(3):201-12. https://doi.org/10 .1097/00005650-199303000-00002

12. Roos LL, Gupta S, Soodeen R-A, Jebamani L. Data quality in an information-rich environment: Canada as an example. Can J Aging. 2005;24 Suppl 1:153-70. https://doi.org/10.1353 /cja.2005.0055

13. Hinds A, Lix LM, Smith M, Quan $H$, Sanmartin C. Quality of administrative health databases in Canada: a scoping review. Can J Public Health. 2016;107(1):e56-e61. https://doi.org/10 $.17269 /$ cjph. 107.5244

14. University of Manitoba Office of Research Ethics \& Compliance. Research requiring ethics review [Internet]. Winnipeg (MB): University of Manitoba; 2019 [cited 2020 Jul 23]. Available from: https://www.umanitoba.ca/research /orec/ethics_medicine/requiring_ review.html
15. Manitoba Centre for Health Policy. Manitoba population research data repository data descriptions [Internet]. Winnipeg (MB): University of Manitoba; 2020 [cited 2021 May 6]. Available from: https://umanitoba.ca/faculties/health _sciences/medicine/units/chs /departmental_units/mchp/resources /repository/descriptions.html?ds $=$ Insurance

16. Lix LM, Walker R, Quan H, Nesdole $R$, Yang J, Chen G. Features of physician services databases in Canada. Chronic Dis Inj Can. 2012;32(4):186-93.

17. Broemeling A-M, Kerluke K, Black C, Peterson S, MacDonald A, McKendry R. Developing and maintaining a population research registry to support primary healthcare research. Healthc Policy. 2009;5(Spec No):65-76.

18. Tang K, Lucyk K, Quan H. Canadian data sources on ethnic classifications [abstract]. J Gen Intern Med. 2016 May; 31(Suppl 2):S144-S145.

19. Ellison J, Nagamuthu C, Vanderloo S, McRae B, Waters C. Estimating chronic disease rates in Canada: which population-wide denominator to use? Health Promot Chronic Dis Prev Can. 2016;36(10):224-30. https://doi.org/10 $.24095 /$ hpcdp.36.10.03

20. Jin Y. Comparison of Alberta population counts between the AHCIP Registry and the 2006 Census. Edmonton (AB): Alberta Health and Wellness; 2009. 80 p. Available from: https://open .alberta.ca/publications/9780778582502 \#detailed

21. Danese MD, Halperin M, Duryea J, Duryea R. The Generalized Data Model for clinical research. BMC Med Inform Decis Mak. 2019;19(1):117. https:// doi.org/10.1186/s12911-019-0837-5

22. Canadian Institute for Health Information (CIHI). Proposed standards for race-based and Indigenous identity data collection and health reporting in Canada. Ottawa (ON): CIHI; 2020. 32 p.

23. Health Data Research Network Canada. About [Internet]. Vancouver (BC): Health Data Research Network Canada; 2020 [cited 2020 Sep 28]. Available from: https://www.hdrn.ca/en/about 